\title{
La Navidad y la Epifanía en las Tradiciones de Ricardo Palma
}

\author{
César Coloma Porcari \\ Instituto Latinoamericano de Cultura y Desarrollo \\ sillardearequipa@gmail.com
}

\section{Resumen}

Trabajo de investigación sobre la descripción que hace Ricardo Palma de las fiestas de la Navidad y la Epifanía en el Perú virreinal y decimonónico. Los Nacimientos, la imaginería, la danza de las pallas, los cantores y cantoras, los “orines" del Niño, la Epifanía, el Paseo de Alcaldes y la Epifanía en la cultura popular.

Palabras clave: Fiestas, Navidad, Epifanía.

\begin{abstract}
Research work on Ricardo Palma's description of the celebrations of Christmas and Epiphany, in colonial and nineteenth-century Peru. Nativity scenes, imagery, the dance of the "pallas", male and female singers, Infant Jesus "urine", the Epiphany, the Mayors Procession and the Epiphany in popular and lower class culture.
\end{abstract}

Keywords: Holidays, Christmas, Epiphany. 


\section{César Coloma Porcari}

Presidente del Instituto Latinoamericano de Cultura y Desarrollo, Miembro de Número del Instituto Ricardo Palma y Miembro de Número del Centro de Estudios HistóricoMilitares del Perú. 
Celebraciones como la Navidad y la fiesta de los Reyes Magos fueron muy importantes en el Perú. Don Ricardo Palma, en sus Tradiciones, nos ofrece algunos datos sobre dichas fiestas. De todos modos, aunque escasa, la información que nos ofrece nos permite conocer, en parte, la manera cómo eran esas fiestas en nuestro país, tanto en la época virreinal como en el siglo XIX. En este ensayo nos ocupamos de estudiar la descripción que Palma hace de las fiestas navideñas, y de su mención a la de los Santos Reyes.

Nosotros hacemos un comentario especial acerca de la fiesta de la Epifanía, que casi ha desaparecido por completo en el Perú actual pero que subsiste en algunos pueblos de la sierra y en los barrios populares de algunas ciudades en donde se asemeja, más bien, a las modernas "polladas", como se verá más adelante.

\section{Los Nacimientos}

La Real Academia Española define al Nacimiento o Belén como "representación con figuras, etc., del [nacimiento] de Nuestro Señor Jesucristo en el portal de Belén” (DRAE, 1826: 978). Y en su tradición "El mes de diciembre en la antigua Lima" (Palma, 1968: 1199), don Ricardo recuerda que "Como los altares de Purísima, eran los nacimientos motivo de fiesta doméstica”.

Agrega el tradicionista que: “armábase en algunas casas un pequeño proscenio, sobre el que se veía el establo de Belén con todos los personajes de que habla la bíblica leyenda. Figurillas de pasta o de madera, más o menos graciosas, completaban el cuadro". Asimismo, "Todo el mundo, desde las siete hasta las once de la noche, entraba con llaneza en el salón, donde se exhibía el divino misterio. Cada nacimiento era más visitado y comentado que ministro nuevo". 
Estos Nacimientos eran armados, en las casas de las familias pudientes, sobre grandes mesas o cómodas. Allí se colocaban las piezas de imaginería, que no siempre guardaban proporción entre ellas. Las figuras principales eran San José, la Virgen, el Niño Dios, el burro y la vaca. Se agregaban pastores y corderos y otros animales. Y había dos tipos de Reyes Magos. Unos montados en camellos o caballos y otros de pie o de rodillas. Los primeros se colocaban lejos del pesebre, y los últimos, cerca de la Epifanía, junto a éste, adorando al Niño (Coloma, 2008).

En los Nacimientos de mayor extensión se incluía pequeñas imágenes representando a Adán y Eva junto a un árbol con vistosas frutas, e inclusive, a Judas ahorcado en otro árbol. También incluían, en esos casos, grandes cantidades de ovejas, con sus pastores, y a personajes curiosos, como escribanos, vendedores de frutas y golosinas, etc.

Algunas veces el Nacimiento se encontraba dentro de una vistosa urna de cristal y madera tallada y dorada, o con espejos. En esos casos las urnas en donde se encontraban los Nacimientos se exhibían permanentemente sobre cómodas, mesas o consolas, en los salones de la casa (Coloma, 2008).

En esa misma tradición, "El mes de diciembre en la antigua Lima" (Palma, 1968: 1199), el gran maestro afirma que "El más famoso de los Nacimientos de Lima era el que se exhibía en el convento de los padres bethlemitas o barbones. Y era famoso por la abundancia de muñecos automáticos y por los villancicos con que festejaban al Divino Infante".

Debemos resaltar esta información de Palma debido a que los "muñecos automáticos" que menciona, llamados "autómatas", fueron creaciones europeas realizadas, generalmente, en el siglo XVIII a base de instrumentos similares a los de la relojería. Eran muy costosos a principios del siglo XIX. Y es muy curioso que 
hubieran llegado al Perú ese tipo de autómatas y que con ellos se formara un Nacimiento.

En su tradición Los Barbones (Palma, 1968: 441-443). Recuerda ese famoso Nacimiento que tenían los frailes bethlemitas de Lima y que conoció él en su niñez. Nos cuenta que este ocupaba un gran ambiente del convento de dichos frailes, y estaba conformado por "figuras de automático movimiento". Destacaba entre estas "el Niño, que movía la manita como para bendecir a los rapazuelos que lo contemplábamos boquiabiertos".

Palma cuenta que "Allí se veía a los Reyes Magos, el blanco, el indio y el negro, lujosamente ataviados, descendiendo de un cerro sobre el portal de Belén, y seguidos por un perro que movía la cola". Además, el Nacimiento mostraba a distintos personajes, e inclusive "Allí estaba Judas haciendo zapatetas, pendiente de un árbol", y también, "casi todos los tipos populares de la ciudad figuraban en efigie en el Nacimiento de Barbones".

En los hogares de escasos recursos, el Nacimiento también era pobre y muy pequeño. Y las figuras que lo constituían no llamaban la atención por su calidad. Pero sus dueños se esforzaban en darle la mejor apariencia para poder reunir a la familia en torno a este.

\section{Las pallas}

El tradicionista recuerda que en las celebraciones de la Navidad participaban las "pallas que bailaban frente al Nacimiento". Las "pallas", en el Perú, eran una "Cuadrilla de indios e indias que suelen ir bailando de pueblo en pueblo, especialmente en tiempo de Navidad" (Espasa, 1920: XLI, 529). Lamentablemente no se conserva esta antigua tradición limeña, que debe haber desaparecido a fines del siglo XIX. Tampoco se tiene noticia de 
cómo era la danza, ni la música que la acompañaba. Solamente sabemos que las danzantes portaban altas varas en las cuales se sujetaban, con mucha gracia, ornamentos de papel picado, flores artificiales, estrellas y lunas. Pancho Fierro pintó varias acuarelas en donde representa a esas pallas limeñas. Estas antiguas "pallas" de la Ciudad de los Reyes no tienen ninguna relación con las actuales pallas de Corongo y otros lugares de la Sierra central.

En "El mes de diciembre en la antigua Lima" Palma nos cuenta que "La nochebuena, con su misa de Gallo, era el no hay más allá del criollismo. Desde las cinco de la tarde del 24 de diciembre, los cuatro lados de la Plaza Mayor ostentaban mesitas, en las que se vendían flores, dulces, conservas, juguetes, pastas, licores y cuanto de apetitoso y manducable plugo a Dios crear".

Agrega que "A las doce [de la noche], solo el populacho quedaba en la plaza multiplicando las libaciones. La aristocracia y la clase media se encaminaban a los templos, donde las pallas cantaban en el atrio villancicos como este:

Arre, borriquito, vamos a Belén, que ha nacido un niño para nuestro bien.

Arre, borriquito, vamos a Belén, que mañana es fiesta, pasado también”.

\section{Cantores y cantoras}

Palma menciona, en Los Barbones, a la "banda de cantores y músicos dirigida por el maestro Hueso o el maestro Bañón”, que actuaban en el Nacimiento de los frailes barbones. Afirma que 
"Las coplas que se cantaban, siempre regocijadas y picarescas, eran hijas de la musa popular, así española como limeña". Y agrega que "Oírlas cantar por las cantoras y cantores criollos constituía el principal atractivo para el crecido concurso que se arremolinaba en Barbones; y así lo comprendieron los benditos hospitalarios, que probaron ser de manga ancha al no oponer su veto a ciertas jácaras licenciosas" (Palma, 1968: 443-444).

\section{Los “orines" del Niño}

En esta tradición, "Los Barbones", cuenta también que los frailes "agasajaban a la concurrencia" con los famosos "orines del Niño" (Palma, 1968: 442). Con ese poco higiénico nombre se conocía, en las fiestas de Navidad y Epifanía, a la "dulcísima aloja o chicha morada", tradicional bebida no alcohólica, típica de la Ciudad de los Reyes, la cual era elaborada cociendo el maíz morado, variedad del Zea mays L. originaria del Perú.

\section{La imaginería}

En la tradición "La trenza de sus cabellos" (Palma, 1968: 554), al referirse al gran escultor Baltasar Gavilán, afirma:

Baltasar, para distraerse en su forzada vida monástica, empezó por labrar un trozo de madera y hacer de él los bustos de la Virgen, el niño Jesús, los tres Reyes Magos y, en fin, todos los accesorios del misterio de Belén. Aunque las figuras eran de pequeñas dimensiones, el conjunto quedó lucidísimo y los visitantes del guardián propalaban que aquello era una maravilla artística. Alentado con los elogios, Gavilán se consagró a hacer imágenes de tamaño natural, no sólo en madera, sino en piedra de Huamanga, algunas de las cuales existen en diversas iglesias de Lima. 
En su tradición Haz bien sin mirar a quien (Palma, 1968: 556), al referirse a la fiesta de los Reyes Magos en Quequeña, don Ricardo Palma menciona a "una chica de dieciocho eneros, con más garbo que una reina y con más ángel en la cara que un retablo de Navidad". Y en La venganza de un cura (Palma, 1968: 1 103), al narrar los hechos que ocurrieron luego de la batalla de Ingavi, se refiere a ese fraile indicando que "El devoto clérigo tenía en su casa un precioso Nacimiento..., y el Niño Jesús era... de plomo". Y ese fraile, "en aras de la patria, supo hacer el sacrificio de sus escrúpulos y sentimientos religiosos", y fundió el Niño Dios de plomo para hacer balas. Palma las llama socarronamente "las balas del Niño Dios".

No son muchos los imagineros que sobreviven en el Perú. En la ciudad del Cuzco se concentra un grupo de ellos. Debido a esta razón es que las imágenes que se producen para los Nacimientos, actualmente, son de bajísima calidad. Además, sus materiales son muy pobres, como el yeso, y todos están vaciados en ordinarios moldes y pintados de colores estridentes. E inclusive hay ahora Nacimientos hasta de plástico, que llegan al Perú desde el lejano Celeste Imperio. Es decir que los budistas fabrican las imágenes católicas que invaden nuestros mercados.

También debemos recordar que en la actualidad, muchas personas de escasos recursos arman su Nacimiento, no solamente utilizando las imágenes de yeso y de plástico que comentamos sino que, además, construyen una abultada mole forrada en papel de color marrón, salpicado de verde, para formar una especie de cueva, donde colocan las imágenes mencionadas. 


\section{La Epifanía}

El tradicionista, en esta naracción de El mes de diciembre de la antigua Lima, cuenta que "como todo tiene fin sobre la tierra, el 6 de enero, día de los Reyes Magos, se cerraban los nacimientos. De suyo se deja adivinar que aquella noche el holgorio era mayúsculo". No menciona ninguna celebración especial por la fiesta de los Reyes de Oriente, porque no existía en su época.

Debemos recordar que en diversos lugares del Perú se celebraba la fiesta de la Epifanía el 6 de enero de cada año. En Tiabaya (Arequipa) se ha conservado esta festividad, pero en otros lugares ha desaparecido. El tradicionista recuerda la antigua fiesta de los Reyes Magos que se celebraba en el pueblo de Quequeña (Arequipa), en su tradición "Haz bien sin mirar a quien" (Palma, 1968: 555).

En ella nos dice:

A cinco leguas de Arequipa encuéntrase el pueblo de Quequeña, donde el 6 de enero de 1737 celebrábase, con la animación que hasta hoy se acostumbra, la fiesta de los Reyes Magos. Los habitantes de la ciudad del Misti habíanse dado cita para la alameda que une Quequeña con el, por entonces, caserío de Yarabamba, espaciosa alameda formada por corpulentos sauces plantados en regularidad de diez en diez varas.

También se refiere, socarronamente, a los amantes del alcohol y a sus tres "Reyes Magos", en "La desolación de Castrovirreina" (Palma, 1968: 413).

"Los tres reyes de Oriente:

Vino, chicha y aguardiente". 


\section{El Paseo de Alcaldes en la Epifanía}

La Ciudad de los Reyes, Lima, recibió ese nombre por los Tres Reyes Magos. Fue fundada el 18 de enero de 1535, doce días después de la fiesta de la Epifanía, y al concederle su escudo de armas, el Emperador Don Carlos V consagró perpetuamente la dedicación de la ciudad a los Tres Reyes de Oriente, al lucirse, en el escudo, sus tres coronas de oro bajo la estrella de Belén.

Por ello, todos los años, el día de la Epifanía, se celebraba en Lima con una gran ceremonia cívica y militar, en conmemoración de la fundación de la ciudad y en homenaje y reconocimiento al monarca reinante, llamada popularmente "Paseo de Alcaldes".

En “La casa de Francisco Pizarro" (Palma, 1968: 36), el tradicionista afirma que "Anualmente, el 6 de enero, se efectuaba en Lima la gran procesión cívica conocida con el nombre de paseo de alcaldes". En esta, señala

El virrey, oidores, estudiantes, miembros de la Real y Pontificia Universidad de San Marcos y todos los personajes de la nobleza, así como los jefes de las oficinas del Estado, se presentaban en magníficos caballos lujosamente enjaezados. Tras de cada caballero iban dos negros esclavos, vestidos de librea y armados de gruesos plumeros con los que sacudían la crin y arneses de la cabalgadura. Los inquisidores y eclesiásticos acompañaban al arzobispo, montado en mulas ataviadas con no menos primor.

Asimismo, debido a que "El estampido de las camaretas y cohetes se hacía más atronador", entre "los vivas y gritos de la muchedumbre se dirigía la comitiva a la Alameda". Y "Las damas de la aristocracia presenciaban desde los balcones el desfile de la comitiva, o acudían en calesín, que era el carruaje de moda, a la Alameda, luciendo la proverbial belleza de las limeñas". 


\section{La Epifanía en la cultura popular}

Como ya lo hemos señalado, Palma, en su obra, no se refiere a ninguna costumbre peculiar referente a la fiesta de la Epifanía en la Ciudad de los Reyes, fuera del "Paseo de Alcaldes". En su tradición que estamos estudiando: El mes de diciembre de la antigua Lima (Palma, 1968: 1 199), solamente recuerda que el 6 de enero "se cerraban los nacimientos" y que "De suyo se deja adivinar que aquella noche el holgorio era mayúsculo".

Debe haber sido a fines del siglo XIX en que apareció, en Lima, una nueva costumbre, exclusiva de las clases populares, la que consistía en elegir "padrinos" de los Reyes Magos, del Nacimiento de sus casas. Estos "padrinos" quedaban obligados a aportar pequeñas sumas de dinero, a los dueños de casa, el 6 de enero. Se armaban grandes jaranas en donde se libaba licor, produciéndose, a veces, graves incidentes con la policía.

Nos cuenta don José Gálvez, en su obra Estampas Limeñas, que "En los hogares pobres, las gentes sencillas" colocaban "un platillo para recibir las limosnas para los 'orines del Niño". Y en esos "Nacimientos populares se divertían todos desde el 24 de diciembre hasta el día de Reyes, y se armaban jolgorios grandes" (Gálvez, 1966: 21-23).

El Dr. Gálvez recuerda también los callejones, corralones y casas de vecindad de Lima:

La jarana era de las gordas el día de la bajada de los Reyes, con los padrinos, nombrados con anticipación. Obsequiaban algo para el Nacimiento del diciembre por venir, o corrían con el gasto de la fiesta en los hogares pobres. El último día de la zambra y el bullicio subían de punto y hasta de contrapunto, y en presencia del sagrado Misterio, los mozos malos hacían de las suyas (...). Y a la calle iban exaltados, 
armándose zalagarda y marimorena menudeadora de golpes y palabras gruesas hasta la llegada de la policía.

En los últimos años, algunos grupos de personas pertenecientes al proletariado urbano, así como los migrantes asentados en la periferia de las ciudades, en los llamados anteriormente "pueblos jóvenes" o "barriadas", han creado una nueva fiesta, que ellos llaman "Bajada de Reyes".

En ella se ha reinterpretado la fiesta de las clases populares del siglo anterior, llamada con mayor propiedad "Bajada de los Reyes”, que describe don José Gálvez, como ya lo hemos visto. Pero la actual "Bajada de Reyes" tiene una connotación diferente, ya que es muy similar a las actuales "polladas", y, como estas, es practicada exclusivamente por personas pertenecientes a los estratos de menores recursos económicos.

En esa mal llamada "Bajada de Reyes" los "padrinos" le entregan dinero al dueño de casa, el cual es empleado en la adquisición de bebidas alcohólicas generalmente en exceso por los asistentes a la fiesta. Y los "padrinos" tienen la obligación de desarmar el Nacimiento, envolviendo las muy frágiles imágenes de yeso, o las más resistentes de plástico, en papeles, y colocándolas en una caja en donde el dueño de casa las conservará hasta el año siguiente.

Está de más recordar que las personas de los estratos más elevados no celebran ni han celebrado esa mal llamada "Bajada de Reyes". Lo que acostumbraban era ir a misa ese 6 de enero, que fue feriado hasta hace unos lustros, y disfrutar de la "rosca de Reyes", de origen netamente hispano.

Debemos tener presente que en las "polladas", que hemos mencionado al referirnos a esta "Bajada de Reyes", las personas de escasos recursos demuestran una solidaridad ejemplar 
para con sus familiares o amigos. Generalmente las organiza alguien con el fin de proveerse de dinero para construir nuevas paredes o un techo en su casa, o para sufragar los gastos de una intervención quirúrgica. En esos casos el fin sería sumamente positivo.

Pero también realizan polladas con fines nada edificantes, como por ejemplo, para conseguir fondos para una fiesta o algo similar. En este caso los asistentes a la "actividad" (como la llaman), bailan, beben, comen los pollos preparados especialmente para la ocasión y el dinero recaudado no se invierte en nada positivo.

\section{Bibliografía}

Coloma Porcari, C. (2008). Los antiguos Nacimientos del Perú. En Voces, Revista Cultural de Lima, año 9, № 35, pp. 48-51. Lima: Solsticios\& La Tymele Producciones.

Enciclopedia Universal Ilustrada Europeo-Americana. (1920). Madrid: Talleres tipográficos de la Editorial Espasa-Calpe.

Gálvez, J. (1996). Estampas Limeñas. Lima: Imprenta de la Universidad Nacional Mayor de San Marcos.

Gonzales Arnao. V. (Ed. Abrev.) (1822). Diccionario de la Academia Española. Madrid (lera parte). París: Librería de Parmantier, Imprenta de Cosson (2da parte).

Palma, R. (1968). Tradiciones Peruanas Completas. Madrid: Aguilar S. A. de Ediciones, Selecciones Gráficas. 